\title{
PROSPEK KELAYAKAN PENGEMBANGAN BUDIDAYA IKAN NILA DI KOLAM AIR TENANG DI KECAMATAN SINJAI BORONG KABUPATEN SINJAI
}

\author{
Prospects for the Feasibility of Developing Tilapia Aquaqulture In Calm Water Ponds In The Sinjai Borong Sub District of Sinjai
} District

\author{
Jamaluddin Saleh ${ }^{1}$, Sutia Budi ${ }^{2}$, Suryawati Salam ${ }^{3}$ \\ ${ }^{1}$ Dinas Kelautan dan Perikanan Kabupaten Sinjai \\ ${ }^{2}$ Program Studi Budidaya Perairan Universitas Bosowa \\ ${ }^{3}$ Program Studi Agribisnis Universitas Bosowa \\ Email: jjamaluddinsaleh@gmail.com \\ Diterima : 08 September 2019 \\ Dipublikasikan : 09 Desember 2019
}

\begin{abstract}
ABSTRAK
Penelitian ini bertujuan untuk mengetahui tingkat kelayakan dan prospek pengembangan budidaya ikan nila di kolam air tenang di Kecamatan Sinjai Borong Kabupaten Sinjai. Populasi dalam penelitian ini adalah pembudidaya ikan nila di kolam air tenang yang ada di Kecamatan Sinjai Borong Kabupaten Sinjai yaitu sebanyak 163 orang pembudidaya, sampelnya sebanyak 30 orang responden ditentukan dengan menggunakan metode purposive sampling berdasarkan pengetahuan dan pengalaman dalam pengelolaan usaha pembesaran ikan nila di kolam air tenang. Data yang yang diperoleh dianalisis dari aspek teknis, aspek finansial, dianalisis dengan analisis SWOT dan analisis trend produksi menggunakan metode kuadrat terkecil. Hasil penelitian menunjukkan bahwa dari aspek teknis layak untuk dikembangkan, aspek finansial tidak layak untuk kelayakan investasi dan Analisis SWOT menunjukkan pada posisi dapat dipertahankan untuk dikembangkan dengan memanfaatkan peluang yang ada dengan meminimalkan ancaman dan kelemahan. Hasil analisis trend menunjukkan bahwa produksi ikan nila memiliki kecenderungan terus meningkat meskipun tidak signifikan.
\end{abstract}

Kata Kunci: Prospek Kelayakan, Pengembangan, Ikan Nila.

\section{ABSTRACT}

This research is a case study that aims to determine the level of feasibility and prospects for the development of tilapia aquaculture in calm water ponds in Sinjai Borong Sub-District, Sinjai Regency. The population in this study were tilapia fish farmers in calm water ponds in Sinjai Borong District, Sinjai Regency, as many as 163 farmers, the sampel of 30 respondent was determined using a purposive sampling method based on knowledge and experience in managing of tilapia enlargement business in calm water ponds. The study was conducted in June to July 2019. The data obtained were analyzed from technical aspects, analyzed by SWOT analysis and production trend analysis using the least squares method. The results showed that from the technical aspects feasible to be developed, the financial aspects were not feasible for investment feasibility and the SWOT analysis showed that position could be maintained to be developed by utilizing existing opportunities by minimizing threats and weaknesses. The results of ternd analysis show the tilapia production has a tendency to increase even though it is not significant.

Keywords : Prospect of Feasibility, Development, Tilapia

\section{PENDAHULUAN}

Ikan Nila memiliki prospek komersial yang paling menjanjikan saat ini disediakan oleh sejumlah spesies ikan, salah satunya adalah ikan nila. Kebutuhan ikan nila di Sulawesi Selatan terus meningkat dari tahun ke tahun, sehingga kegiatan pembudidayaan perlu ditingkatkan guna memenuhi permintaan pasar dan kebutuhan gizi masyarakat.

Dukungan kondisi eksisting kawasan di Kabupaten sinjai dalam bidang perikanan mempunyai prospek bisnis yang menjanjikan, sehingga diperlukan penelitian tentang strategi pengembangan supaya usaha tersebut lebih menguntungkan lagi dan bisa dijadikan andalan utama. Langkah awal dalam menyusun strategi pengembangan adalah dengan menganalisis usaha budidaya ikan nila di lokasi penelitian, kemudian menentukan kebijakan yang harus dilaksanakan.

Dari beberapa wilayah yang potensial untuk pengembangan budidaya ikan nila di kabupaten Sinjai,
Kecamatan Sinjai Borong merupakan salah satu targetnya. Dari sisi Iklim, kecamatan Sinjai Borong sangat cocok untuk dijadikan sebagai lokasi pengembangan ikan nila, karena berdasarkan tipe iklim oldeman, wilayah kabupaten Sinjai termasuk ke dalam tipe iklim C hingga D. Banyaknya curah hujan hingga tahun 2000 mencapai 9.785 mm. Temperatur di kawasan perairan kabupaten Sinjai berkisar antara 25$32^{\circ} \mathrm{C}$ Kondisi ini mendukung keberadaan ekosistem perairan di Kabupaten Sinjai khususnya Kecamatan Sinjai Borong (Dinas Perikanan Sinjai, 2018).

Sehubungan dengan semakin meningkatnya produksi ikan maka perlu mempertahankan dan mengembangkan usaha budidaya ikan nila dengan sebaik mungkin agar pembudidaya tidak mengalami kerugian, untuk itu perlu pengkajian tentang prospek kelayakan pengembangan budidaya ikan nila khususnya di kolam air tenang. 


\section{METODE PENELITIAN}

\section{Lokasi dan Waktu Penelitian}

Lokasi penelitian berada di Desa Biji Nangka, Desa Batu Belerang dan Desa Barambang Kecamatan Sinjai Borong Kabupaten Sinjai. Pemilihan lokasi penelitian dilakukan secara sengaja (purposive), karena lokasi tersebut merupakan sentra produksi Ikan Nila di Kecamatan Sinjai Borong. Selain itu daerah ini juga berpotensi untuk membudidayakan Ikan Nila. Adapun jadwal penelitian dilaksanakan pada Bulan Juni sampai dengan Bulan Juli 2019.

\section{Jenis dan Sumber Data}

Data yang akan digunakan dalam rencana penelitian ini adalah data primer dan data sekunder. Dengan menggunakan daftar pertanyaan (kuisioner) yang telah disiapkan terlebih dahulu serta wawancara sesuai data yang dibutuhkan dalam penelitian. Data primer didapatkan dari responden melalui metode wawancara dan kuesioner. Data sekunder dikumpulkan dari literatur - literatur yang releven seperti buku, surat kabar, dan dinas atau instansi yang terkait, seperti Dinas Perikanan Kabupaten Sinjai, situs resmi departemen terkait, perpustakaan dan instansi lainnya yang dapat membantu untuk ketersediaan data.

\section{Analisis Data}

Analisis Aspek Teknis dan aspek finansial

Aspek teknis dianalisis secara deskriptif. Analisis ini meliputi lokasi usaha, luas produksi pemilihan jenis teknologi. Analisis aspek finansial pada usaha yang dijalankan Pembudidaya Ikan Nila dilakukan dengan mengerjakan serangkaian perhitungan kuantitatif. Kegiatan yang dianalisis adalah budidaya Ikan Nila. Analisis yang dilakukan dalam aspek finansial mencakup analisis biaya dan manfaat, nilai arus tunai (cash flow), kemudian dilakukan dengan perhitungan beberapa kriteria investasi, yaitu Net Present Value (NPV) Net Benefit Per Cost (B/C Ratio), Internal Rate Return (IRR) dan Payback Period (PP Tahapan pengolahan data meliputi pengumpulan data (di lapang), pemasukkan data, editing data, lalu penghitungan dengan menggunakan kalkulator dan komputer dengan program microsoft excel 2007.

\section{Analisis SWOT}

Dalam penelitian ini peneliti membagi kuisioner yang disusun dalam kalimat- kalimat pernyataan. Responden diminta memberikan tanggapannya dengan memilih salah satu pilihan jawaban. Jawaban responden yang bersifat kualitatif dan kuantitatif dan diukur dengan menggunakan skala likert. Skala likert yaitu skala yang berhubungan dengan pernyataan sikap seseorang terhadap sesuatu yang diukur dengan menggunakan skala lima poin.

Setelah mendapatkan faktor internal dan eksternal maka untuk menentukan hasil analisis SWOT guna menemukan strategi maka faktor internal dan eksternal tersebut di "likert". Adapun angka likert nya yaitu dari 1-5. Angka 1 menunjukkan Sangat Tidak Baik (STB), angka 2 menunjukkan Tidak Baik (TB), angka 3 menunjukkan Ragu-ragu (RR), angka 4 menunjukkan Baik (B) dan angka 5 menunjukkan Sangat Baik (SB).

Dengan begitu akan dapat ditentukan berbagai kemungkinan alternatif strategi yang dapat dijalankan (Rangkuti,2015) Hasil SWOT ini nantinya akan digunakan untuk mengidentifikasikan dan merekomendasikan strategi pengembangan subsektor perikanan budidaya Ikan nila di kolam air tenang di Kecamatan Sinjai Borong.

\section{Identifikasi Faktor-Faktor Internal dan Eksternal}

Dengan memecah semua unsur kekuatan (strength), kelemahan (weakness), peluang (opportunity) dan ancaman (threats) untuk mendapatkan tentang data prospek kelayakan pengembangan subsektor perikanan budidaya Ikan nila di kolam air tenang di Kecamatan Sinjai Borong dihimpun daftar pertanyaan (kuisioner), yang berisi seperangkat pernyataan yang telah dirancang sesuai dengan dimensi dan variabel untuk masing-masing faktor kekuatan, kelemahan, peluang dan ancaman.

\section{HASIL DAN PEMBAHASAN}

\section{Keadaan Lokasi Penelitian}

\section{Letak geografis, batas dan luas wilayah}

Kecamatan Sinjai Borong terdiri dari terdiri dari 7 desa dan 1 kelurahan, semua desa/kelurahan yang ada di Kecamatan Sinjai Borong bukan merupakan wilayah pantai karena letak kecamatan ini berada di dataran tinggi dengan rata- rata ketinggiaan $800 \mathrm{~m}$ lebih di atas permukaan laut. Jarak ibukota kecamatan Sinjai borong (kelurahan Pasir putih) ke ibukota kabupaten sekitar 42 $\mathrm{km}$. Berdasarkan letak geografis wilayah, Kecamatan Sinjai Borong memiliki batas-batas wilayah sebagai berikut :

- Sebelah utara : Kecamatan Sinjai Tengah

- Sebelah Timur : Kecamatan Sinjai Selatan

- Sebelah Selatan : Kabupaten Bulukumba

- Sebelah Barat : Kecamatan Sinjai Barat

Secara topografi Kecamatan Sinjai Borong merupakan daerah pengunungan yang berada di ketinggian \pm 750 1000 mdpl dengan luas $\pm 66,97 \mathrm{~km}^{2}$ daerah ini beriklim tropis dengan curah hujan $1000 \mathrm{~mm} /$ tahun suhu harian rata-rata $\pm 20^{\circ} \mathrm{C}$.

\section{Tata Guna Lahan}

Kecamatan Sinjai Borong sebagai lokasi penelitian memiliki daerah yang memiliki karakteristik dalam pola penggunaan lahannya. Dari $6697 \mathrm{Ha}$ luas wilayah Kecamatan Sinjai Borong terdapat seluas 24 Ha lahan yang di manfaatkan masyarakat untuk usaha budidaya ikan air tawar di kolam. Hal ini menunjukkan masih minimnya ketertarikan masyarakat di Kecamatan Sinjai Borong melakukan usaha budidaya ikan Nila di kolam air tenang.

\section{Keadaan Penduduk}

Jumlah penduduk yang ada di Kecamatan Sinjai Borong adalah sebanyak 16.133 jiwa, terdiri dari lakilaki 7.989 jiwa dan perempuan 8.144 jiwa. Dari data dapat diklasifikasikan bahwa kelompok umur produktif antara 15 - 64 tahun memiliki jumlah terbanyak hal tersebut mengidentifikasikan bahwa masyarakat yang ada di Kecamatan Sinjai Borong memiliki usia produktif yang relatif tinggi dan ini menjadi potensi dalam kegiatan usaha budidaya ikan nila. 


\section{Sarana Dan Prasarana}

Sarana dan prasarana di Kecamatan Sinjai Borong di nilai cukup baik. Seperti sarana ibadah yang berjumlah 43 unit masjid dan 9 mushollah, Sarana pendidikan berjumlah 53 unit, sarana kesehatan 41 unit, sarana transportasi berupa angkutan darat sebanyak 254 unit, hal ini menunjukkan bahwa sarana transportasi sudah cukup memadai. Sarana perdagangan seperti pasar umum sebanyak 4 unit, kios hasil bumi sebanyak 109 unit dan warung makan sebanyak 2 unit menjadi penunjang dalam pemasaran hasil produksi budidaya ikan nila.

\section{Kelayakan Aspek Teknis Usaha Budidaya Ikan Nila}

Aspek teknis kelayakan usaha diukur dari beberapa kriteria. Kriteria tersebut di antaranya kriteria Penentuan lokasi, luasan produksi, penggunaan teknologi, dan layout (proses) produksi. Kriteria - kriteria tersebut merupakan kriteria yang diharapkan ada untuk mendukung dan memperlancar kegiatan budidaya ikan di Kecamatan Sinjai Borong Kabupaten Sinjai.

Kelayakan teknis Usaha budidaya ikan Nila berdasarkan lokasi di Kecamatan Sinjai Borong Kabupaten Sinjai.

Kelayakan teknis usaha berdasarkan lokasi dari aspek penentuan lokasi dari usaha budidaya ikan nila di Kecamatan Sinjai Borong Kabupaten Sinjai sudah terpenuhi keseluruhan namun belum optimal. Bahan baku yang dibutuhkan seperti bibit dan pakan kurang memadai. Terkait dengan bibit ikan nila para pembudidaya bekerjasama dengan Balai Benih Ikan (BBI) dalam pengadaan bibit. Ketersediaan pakan juga kurang memadai karena harus dibeli di kota dan tidak jarang harus mendapatkan pakan dari luar daerah Kabupaten Sinjai.

Letak pasar untuk menjual hasil produksi ikan nila dapat dijangkau dan di daerah tersebut juga terdapat pedagang besar yang mampu membeli dan menerima hasil produksi. Iklim sudah sesuai untuk pembudidayaan ikan sehingga ikan dapat tumbuh dan berkembang biak secara optimal.

Berdasarkan penjelasan tersebut secara aspek teknis untuk penentuan lokasi usaha budidaya yang ditinjau dari beberapa kriteria dapat dikatakan 'layak', sehingga dengan layaknya lokasi maka terdapat peluang untuk pengembangan usaha budidaya di daerah tersebut.

\section{Kelayakan luasan produksi Usaha budidaya Ikan Nila di} Kecamatan Sinjai Borong Kabupaten Sinjai

Para pembudidaya masih belum memiliki kemampuan yang kuat terkait dengan kondisi finansial hal ini ditandai dengan penggunaan pakan yang rata-rata dilakukan sekali dalam sehari dan pembudidaya masih belum bisa melakukan manajemen yang baik terhadap kegiatan usaha budidaya Ikan nila dimana pembudidaya tidak memiliki pencatatan yang lengkap terkait dengan pengelolaan keuangan, hal ini menggambarkan kondisi manajemen dan finansial pembudidaya masih lemah.

Perubahan teknologi sangat memungkinkan di Kecamatan Sinjai Borong Kabupaten Sinjai karena telah memiliki pendamping dalam penerapan teknologi atau adopsi teknologi yang berkaitan dengan budidaya ikan yakni para penyuluh perikanan. Berdasarkan penjelasan tersebut dapat disimpulkan bahwa terkait aspek teknis untuk luasan produksi dapat dikatakan "layak" karena dari semua kriteria terpenuhi meski belum sempurna seperti kemampuan finansial dan manajemen yang masih lemah namun terpenuhi, seperti halnya ketersediaan tenaga kerja ada namun tidak sesuai dengan kebutuhan pada saat pembuatan dan perbaikan kolam.

Kelayakan Teknis Berdasarkan Teknologi Usaha Budidaya Ikan Nila di Kecamatan Sinjai Borong Kabupaten sinjai.

Penggunaan Teknologi diketahui terkait dengan tersedianya pemasok dan suku cadang dari alat yang digunakan dalam pembudidayaan ikan nila dapat diperoleh di pasar tradisonal. Alat-alat yang digunakan berupa cangkul, jaring dan hapa. Alat-alat tradisonal tersebut mudah untuk diperoleh. Apabila terjadi kerusakan pada alat-alat yang dimiliki pembudidaya, terkait dengan suku cadang dapat dibeli di pasar tradisional di daerah tersebut.

Kemampuan dan kualitas yang diberikan oleh alat tersebut yaitu harus menggunakan tenaga kerja manusia dalam menggunakannya serta kualitas yang diberikan tergantung dari sumberdaya manusia yang menggunakan. Alat - alat bantu budidaya ikan nila tersebut digunakan oleh pembudidaya ikan sampai melewati nilai ekonomis dimana penggunaannya sampai kondisi alat tersebut rusak. Kerusakan dari alatalat yang digunakan pembudidaya ikan tergantung dari cara menggunakan dan perawatan yang diberikan pada alat tersebut, apabila terjadi kerusakan pada alat tersebut pembudidaya ikan bersangkutan berusaha memperbaiki sendiri atau membeli suku cadangnya di pasar tradisional setempat.

Berdasarkan penjelasan tersebut dapat disimpulkan bahwa secara aspek teknis untuk teknologi yang digunakan pembudidaya tergolong "layak" karena semua kriteria terpenuhi. Hal yang perlu diperhatikan adalah alat yang digunakan diharapkan tidak hanya mampu membantu pembudidaya melainkan juga mampu memberikan tingkat efisiensi dalam bekerja sehingga penyerapan tenaga kerja pada usaha budidaya ikan nila di kolam air tenang dapat tercapai.

Kelayakan Teknis Usaha budidaya Ikan Nila di Kecamatan Sinjai Borong Kabupaten Sinjai.

Layout produksi dilihat dari segi penataan kolam dibuat saling berdekatan. Pakan disimpan berdekatan atau berada disatu area dengan kolam. Hal ini dilakukan oleh pembudidaya untuk memudahkan pengangkutan pakan ke kolam. Penataan ini juga berfungsi untuk meningkatkan efisiensi pengangkutan pakan, sehingga pengangkutan dapat dilakukan tanpa mengeluarkan biaya produksi yang berlebih.

Sistem pengairan yang dilakukan oleh pembudidaya di lokasi penelitian umumnya adalah sistem pengairan seri, yaitu sistem aliran air dari satu kolam ke kolam yang lain dengan menggunakan pipa. Saluran air yang dibuat untuk system pengairan ini memiliki ketinggian berkisar 15 - $20 \mathrm{~cm}$ dari permukaan kolam hal ini dilakukan agar ketika pakan ditebar dan berkumpul dipermukaan air, pakan tidak ikut hanyut dan masuk ke kolam yang lain. Penggunaan ruangan atau lahan untuk budidaya ikan sudah cukup maksimal namun beberapa aspek belum terpenuhi secara optimal. 
Berdasarkan penjelasan di atas dapat disimpulkan bahwa untuk aspek teknis layout produksi usaha budidaya ikan dapat dikatakan "layak".

Kelayakan teknis Usaha Budidaya Ikan Nila Berdasarkan on-farm di Kecamatan Sinjai Borong Kabupaten sinjai.

Berdasarkan kelayakan teknis usaha budidaya ikan nila secara aspek on-farm dapat dikatakan 'Layak. Beberapa aspek terpenuhi meski masih belum di lakukan secara optimal dimana proses persiapan lahan dilakukan, pengairan tidak dilakukan secara optimal.

\section{Kelayakan Aspek Finansial Usaha Budidaya Ikan Nila di} Kecamatan Sinjai Borong Kabupaten Sinjai

Nilai Net Present Value (NPV) Usaha Budidaya Ikan Nila Di Kecamatan Sinjai Borong Kabupaten Sinjai.

Fungsi dari Net Present Value (NPV) atau nilai sekarang bersih adalah sebagai analisis manfaat finansial yang digunakan untuk mengukur layak tidaknya suatu usaha dilaksanakan dilihat dari nilai sekarang (present value) arus kas bersih yang akan diterima dibandingkan dengan nilai sekarang dari jumlah investasi yang dikeluarkan .

Hasil dari analisis ini akan menunjukkan Usaha Budidaya Ikan Nila dapat dilanjutkan atau tidak. Salah satu kriteria kelayakan finasial adalah net present value (NPV). Analisis NPV dari Usaha Budidaya Ikan Nila di lokasi penelitian di Kecamatan Sinjai Borong ini merupakan nilai sekarang (present value), dari selisih antara benefit (manfaat) dengan cost (biaya) pada discount rate yang ditentukan yang berlaku pada masa penelitian yaitu sebesar $10 \%$. Dari hasil perhitungan Net Present Value (NPV) menunjukkan bahwa NPV $<0$ yaitu -6.52 per pembudidaya ikan/ responden, maka usaha budidaya ikan nila dapat dinyatakan "Tidak layak ".

Nilai Internal Rate of Return Usaha Budidaya Ikan Nila per pembudidaya di Kecamatan Sinjai Borong Kabupaten Sinjai.

Analisis ini bertujuan untuk mengetahui seberapa lama waktu yang diperlukan untuk mampu mengembalikan biaya investasi yang dikeluarkan. Payback period ini nanti dibandingkan dengan nilai ekonomis suatu usaha tersebut. Untuk melihat nilai IRR Usaha Budidaya Ikan Nila di kolam air tenang di lokasi penelitian dapat dilihat tabel berikut :

Tabel 1. Nilai Internal Rate of Return Usaha Budidaya Ikan Nila di Kecamatan Sinjai Borong Kabupaten Sinjai

\begin{tabular}{lc}
\hline Keterangan & Nilai / pembudidaya \\
\hline Nilai NPV (Rp) & 6.850 .180 \\
Diskon /DF (\%) & 19 \\
Nilai NPV (Rp) & 6.880 .206 \\
Discon / DF (\%) & 20 \\
\hline IRR & $-209,14 \%$ \\
\hline Sumber : Data Primer diolah, 2019 &
\end{tabular}

Dari Tabel 1 Internal Rate of Return (IRR) menunjukkan bahwa IRR $<1$ yaitu $-209,14 \%$ perpembudidaya maka kelayakan usaha budidaya ikan dinyatakan "Tidak Layak “.
Nilai Net B/C Usaha Budidaya Ikan Nila di Kecamatan Sinjai Borong Kabupaten Sinjai.

Analisis untuk efisiensi biaya dinyatakan dalam nilai uang sekarang atau masa penelitian. Pada pengukuran tingkat efisiensi biaya usaha budidaya ikan nila di Kecamatan Sinjai Borong Kabupaten Sinjai yaitu dengan membandingkan besarnya penerimaan total dan pengeluaran total pada tingkat suku bunga yang berlaku pada masa penelitian yaitu sebesar $10 \%$. Perhitungan untuk efisiensi biaya dilakukan dengan Net $\mathrm{B} / \mathrm{C}$ dimana suatu usaha dikatakan layak apabila nilai kriteria tersebut lebih dari satu bila lebih kecil dari satu maka dikatakan tidak layak.

Dari hasil perhitungan dengan kondisi suku bunga atau diskon (DF) $10 \%$,Nilai Net B/C $<1$ dengan nilai untuk per pembudidaya sebesar 0,76. Maka dapat disimpulkan bahwa usaha budidaya ikan nila di kolam air tenang di lokasi penelitian di Kecamatan Sinjai Borong Kabupaten Sinjai “ Tidak Layak “.

\section{Kelayakan aspek Pengembangan budidaya ikan nila Identifikasi Faktor-Faktor yang Berpengaruh}

Berdasarkan pada data primer yang didapatkan dari penyebaran kuisioner terhadap masing-masing responden terhadap variabel faktor internal yang digunakan untuk menentukan kekuatan (strength) dan kelemahan (weakness) serta faktor eksternal untuk mendapatkan peluang (opportunities) dan ancaman (threats).

Menurut Sarkis (2011) dari beberapa faktor internal dikategorikan kekuatan apabila rata-rata jawaban responden memiliki hasil > 3 sedangkan kategori kelemahan apabila rata-rata responden memiliki hasil $<3$. Faktor eksternal dikategorikan peluang apabila rata-rata jawaban responden memiliki hasil > 3 sedangkan dikategorikan ancaman apabila jawaban responden memiliki hasil $<3$.

\section{Analisis SWOT}

Berdasarkan penghitungan Analisis Faktor Internal pengembangan budidaya perikanan air tawar pada Tabel 2 disimpulkan faktor kekuatan yang memiliki nilai skor tertinggi berturut-turut adalah :

1. Ketersediaan debit air untuk budidaya air tawar

2. Manfaat dibentuknya pokdakan

3. Tersedianya lahan untuk pengembangan budidaya

Faktor kelemahan yang memiliki nilai skor tertinggi berturut-turut adalah:

1. Pembiayaan atau modal usaha budidaya

2. Kualifikasi sumber daya manusia

3. Konstruksi kolam ikan yang dibuat seadanya

Tabel 2. Analisis Faktor Internal

\begin{tabular}{clcccc}
\hline No & \multicolumn{1}{c}{ Kekuatan } & $\begin{array}{c}\text { Nilai } \\
\text { Urgensi }\end{array}$ & $\begin{array}{c}\text { Bobot } \\
\text { faktor }\end{array}$ & Rating & Skor \\
\hline 1 & 3.73 & 0.10 & 3 & 0.30 \\
& $\begin{array}{l}\text { Ketersediaan lahan untuk } \\
\text { pengembangan budidaya }\end{array}$ & 4.00 & 0.12 & 4 & 0.48 \\
2 & $\begin{array}{l}\text { Ketersediaan debit air untuk } \\
\text { budidaya }\end{array}$ & 3.70 & 0.10 & 3 & 0.30 \\
3 & $\begin{array}{l}\text { Harga terjangkau bagi konsumen } \\
4\end{array}$ & Akses pasar dalam memasarkan \\
produksi & 3.30 & 0.08 & 3 & 0.24 \\
5 & Manfaat dibentuknya pokdakan & 3.63 & 0.10 & 4 & 0.40 \\
\hline Jumlah & $\mathbf{1 8 . 3 6}$ & $\mathbf{0 . 5 0}$ & & $\mathbf{1 . 7 2}$ \\
\hline Kelemahan & 2.86 & 0.08 & 3 & 0.24 \\
\hline 1 & Ketersediaan Benih & 2.53 & 0.10 & 4 & 0.40 \\
2 & Konstruksi kolam & 2.30 & 0.11 & 4 & 0.44 \\
3 & Sumberdaya manusia & & & & 15
\end{tabular}




\begin{tabular}{cccccc}
4 & Pembiayaan atau modal usaha & 2.23 & 0.13 & 4 & 0.52 \\
5 & Sarana informasi dan promosi & 2.80 & 0.08 & 4 & 0.32 \\
\hline Jumlah & $\mathbf{1 2 . 7 2}$ & $\mathbf{0 . 5 0}$ & & $\mathbf{1 . 9 2}$ \\
\hline & TOTAL & & $\mathbf{1 . 0 0}$ & & $\mathbf{- 0 . 2 0}$ \\
\hline
\end{tabular}

Sumber : Data Primer diolah, 2019

Berdasarkan penghitungan Analisis Faktor Eksternal pengembangan budidaya perikanan air tawar di Kecamatan Sinjai Borong pada Tabel 3 faktor peluang yang memiliki nilai skor tertinggi berturut-turut adalah:

1. Peran pemerintah dalam pengembangan budidaya ikan nila

2. Adanya permintaan pasar produk budidaya ikan nila

3. Peningkatan perluasan kerja pada kegiatan budidaya ikan nila

Faktor ancaman yang memiliki nilai skor tertinggi berturut-turut adalah :

1. Harga pakan yang tinggi

2. Harga yang ditawarkan produk pesaing (ikan air tawar lain)

3. Pengaruh limbah terhadap lingkungan

Tabel 3. Analisis Faktor Eksternal

\begin{tabular}{|c|c|c|c|c|c|}
\hline No & Peluang & $\begin{array}{c}\text { Nilai } \\
\text { Urgensi }\end{array}$ & $\begin{array}{l}\text { Bobot } \\
\text { faktor }\end{array}$ & Rating & Skor \\
\hline 1 & $\begin{array}{l}\text { Tingkat konsumsi masyarakat } \\
\text { terhadap ikan }\end{array}$ & 3.40 & 0,08 & 4 & 0.32 \\
\hline 2 & Adanya permintaan pasar & 3.70 & 0,12 & 4 & 0.48 \\
\hline 3 & $\begin{array}{l}\text { Peningkatan perluasan } \\
\text { kesempatan kerja pada kegiatan } \\
\text { budidaya ikan air tawar }\end{array}$ & 3.57 & 0,10 & 4 & 0.40 \\
\hline 4 & Peluang usaha bagi koperasi & 3.10 & 0,07 & 3 & 0.21 \\
\hline 5 & Peran pemerintah & 3.77 & 0,13 & 4 & 0.52 \\
\hline & Jumlah & 25.56 & $\mathbf{0 . 5 0}$ & & 1.93 \\
\hline \multicolumn{6}{|c|}{ Ancaman } \\
\hline 1 & $\begin{array}{l}\text { Pengaruh Limbah terhadap } \\
\text { lingkungan }\end{array}$ & 2.76 & 0,10 & 4 & 0.40 \\
\hline 2 & $\begin{array}{l}\text { Produk pesaing (ikan air tawar } \\
\text { lain) }\end{array}$ & 2.93 & 0,07 & 3 & 0.21 \\
\hline 3 & Harga yang ditawarkan pesaing & 2.60 & 0,12 & 4 & 0.48 \\
\hline 4 & Harga Pakan & 2.53 & 0,13 & 4 & 0.53 \\
\hline 5 & $\begin{array}{l}\text { Kebijakan antar sektor masih } \\
\text { tumpang tindih }\end{array}$ & 2.83 & 0,08 & 3 & 0.24 \\
\hline \multirow{2}{*}{\multicolumn{2}{|c|}{ Jumlah }} & 5.57 & $\mathbf{0 . 5 0}$ & & 1.86 \\
\hline & & & 1 & & 0.07 \\
\hline
\end{tabular}

Sumber : Data Primer diolah, 2019

Tabel 4. Hasil Analisis SWOT Pengembangan Budidaya Ikan Nila di Kolam Air Tenang di Kecamatan Sinjai Borong

\begin{tabular}{lllll}
\hline No & Komponen & Skor & Selisih & Nilai \\
\hline 1 & Kekuatan $(\mathrm{S})$ & 1.72 & & \\
2 & Kelemahan $(\mathrm{W})$ & 1.92 & & \\
\hline 3 & Peluang $(\mathrm{O})$ & 1.93 & & \\
& & 0.07 & + \\
4 & Ancaman $(\mathrm{T})$ & 1.86 & & \\
\hline \multicolumn{4}{l}{ Sumber: Data Primer diolah, 2019}
\end{tabular}

Dari Tabel 4 terlihat bahwa dalam pengembangan budidaya perikanan ikan nila di kolam air tenang di kecamatan Sinjai Borong memiliki nilai faktor internal dengan bobot kekuatan yang lebih kecil dibanding kelemahannya yakni dengan selisih $(-0.20)$ dan nilai faktor eksternal dengan bobot peluang yang lebih besar dari ancamannya yakni dengan selisih 0.07 dengan selisih nilai negatif pada faktor intenal dan dan selisih positif pada faktor eksternal.

Berdasarkan analisis SWOT diketahui posisi pengembangan perikanan budidaya ikan nila di kolam air tenang di Kecamatan Sinjai borong terletak pada Kuadran III yang berarti kegiatan usaha tersebut berusaha mencapai keuntungan dari peluang yang ada dengan mengatasi kelemahan-kelemahan usaha. Strategi yang harus diterapkan dalam kondisi ini adalah meminimalkan masalah-masalah internal menghadapi berbagai ancaman dan kelemahan internal.

Berdasarkan analisis SWOT telah diketahui posisi pengembangan perikanan budidaya ikan nila di kolam air tenang di Kecamatan Sinjai borong terletak pada Kuadran III yang berarti kegiatan usaha tersebut berusaha mencapai keuntungan dari peluang yang ada dengan mengatasi kelemahan-kelemahan usaha. Strategi yang harus diterapkan dalam kondisi ini adalah meminimalkan masalah-masalah internal menghadapi berbagai ancaman dan kelemahan internal.

\section{Strategi Pengembangan Ikan Nila}

Dari hasil perhitungan Analisis SWOT yang menghasilkan grafik strategi berada pada kuadran III maka strategi yang di gunakan adalah Strategi WO yaitu strategi yang meminimalkan kelemahan untuk memanfatkan peluang yang ada. Berdasarkan penjabaran faktor-faktor item-item tentang faktor kelemahan dan peluang, maka:

\section{Strategi W1,W3,W4-O2,O3,O5}

Memotivasi dan memberikan bantuan kepada pembudidaya ikan untuk diversifikasi usaha di sektor pembenihan. Strategi ini perlu dilakukan untuk memberikan stimulan kepada pembudidaya ikan nila agar dapat mempertahankan keberlanjutan usaha di sektor pembesaran ikan nila. Dari 16 pokdakan yang ada di kecamatan sinjai borong, hanya ada 2 pokdakan yang juga bergerak di sektor pembenihan sehingga tidak maksimal dalam memenuhi kebutuhan pembudidaya berupa bibit ikan nila. Semakin banyak masyarakat yang menggeluti usaha pembesaran ikan nila ini namun tidak dibarengi dengan usaha disektor pembenihan.

\section{Strategi W2,W3 - O5}

Meningkatkan kemampuan sumberdaya manusia dengan memanfaatkan dukungan pemerintah dan mitra usaha. Strategi ini dilakukan karena rata-rata pembudidaya ikan nila di kecamatan sinjai borong dalam melakukan kegiatan budidaya hanya mengandalkan pengetahuan atau keterampilan yang mereka dapat secara otodidak. Hal ini tentunya akan berpengaruh terhadap produktifitas hasil budidaya ikan nila yang mereka lakukan. Pemerintah dalam hal ini pemerintah daerah kabupaten sinjai harus dapat membuat program pelatihanpelatihan atau magang untuk meningkatkan kualifikasi dan keterampilan para pembudidaya ikan nila.

\section{Strategi W4 - O4}

Mendorong terbentuknya koperasi yang bergerak di bidang budidaya air tawar. Strategi ini dilakukan untuk menjawab kesulitan yang dirasakan oleh pembudidaya ikan nila adalah dari segi pembiayaan atau modal usaha. Koperasi yang ada di kecamatan sinjai borong tidak secara khusus membantu para pembudidaya dalam memenuhi kebutuhan permodalan. Dengan dibentuknya Koperasi yang bergerak dibidang budidaya ikan air tawar 
diharapkan akan menggerakkan masyarakat untuk lebih semangat dalam menggeluti budidaya ikan nila khususnya di kolam air tenang.

Strategi W5 - O5

Meningkatkan promosi produk budidaya ikan nila. Strategi ini dilakukan mengingat ikan nila termasuk ikan air tawar yang memiliki kandungan gizi yang seimbang dan cita rasa yang khas. Pemerintah dengan pembudidaya ahrus bersinergi dalam mempromosikan produk hasil budidaya ikan nila ini melalui pameran-pameran, lomba masak dan wisata kuliner yang berbahan dasar ikan.

Tabel 5. Data Produksi dan Nilai Produksi Nila di Kolam Air Tenang di Kecamatan Sinjai Borong Tahun 2015 - 2018

\begin{tabular}{ccc}
\hline Tahun & Produksi Nila (ton) & Nilai Produksi (Rp.000) \\
\hline 2015 & 1,304 & 32.600 \\
2016 & 1,310 & 32.750 \\
2017 & 1,316 & 32.900 \\
2018 & 1,331 & 33.275 \\
\hline
\end{tabular}

Dari data Tabel 5 menunjukan bahwa produksi ikan nila di Kecamatan Sinjai Borong mengalami tren kenaikan, meskipun kenaikan tidak begitu signifikan. Hal ini tidak lepas dari peran pemerintah daerah dalam memotivasi pembudidaya untuk melakukan kegiatan usaha budidaya ikan nila. Bentuk motivasi yang diberikan oleh pemerintah daerah adalah melalui pemberian bantuan bibit dan pakan kepada pokdakan.

Tabel 6. Ramalan Produksi Nila di Kolam Air Tenang di Kecamatan Sinjai Borong

\begin{tabular}{lc}
\hline Tahun & Produksi ikan Nila (Ton) \\
\hline 2019 & 1337 \\
2020 & 1343 \\
2021 & 1349 \\
2022 & 1355 \\
\hline
\end{tabular}

Sumber : Data Primer Diolah, 2019

Ramalan produksi ikan nila pada Tabel 6 berguna bagi pihak-pihak terkait sebagai acuan dalam mempersiapkan pasar. Pembudidaya dapat mempersiapkan berapa jumlah produk ikan nila yang harus dihasilkan untuk memenuhi permintaan pasar.

\section{KESIMPULAN}

Prospek kelayakan pengembangan budidaya ikan nila di kolam air tenang di Kecamatan Sinjai Borong dapat dipertahankan untuk dikembangkan dengan memaksimalkan peluang yang ada dan meminimalkan ancaman dan kelemahan.

\section{DAFTAR PUSTAKA}

Badan Pusat Statistik Kabupaten Sinjai, 2018. Kabupaten Sinjai Dalam Angka 2018

Dinas Perikanan Kabupaten Sinjai, 2018. Statistik Kelautan dan Perikanan Kabupaten Sinjai.

Fachriyan Hilmi Arija, Azis Nur Bambang, Muslim, 2015. Prospek Pengembangan Usaha Agribisnis Ikan Nila (Oreochromus niloticus) di Kawasan Minapolitan
Kabupaten Klaten Propinsi Jawa Tengah. Agromedia,vol.33, No. 1 Maret 2015

Hadie Emmawatie Lies, Endhay Kusnendar, Bambang priono, R. Roro Sri Pudji Sinarni dewi dan Wartono Hadie, 2018. Strategi dan Kebijakan Produksi Pada Budidaya Ikan Nila Berdaya Saing. Jurnal Kebijakan perikanan Indonesia. Vo. 10 No. 2 Nov 2018

Hadijah Siti, Muh. Basir, Lien Damayanti 2015. Analisis Pendapatan dan Strategi Pengembangan Usaha Budidaya Ikan Nila di kecamatan Ampana Kota Kabupaten Tojo Una-Una. J Agroland 22 (3) : 235, Desember 2015

Husnan S dan Muhammad. 2014. Studi Kelayakan Proyek. Unit Penerbit dan Percetakan AMP YKPN. Yogyakarta.

Kurniati Ayu Sri, Jumanto, 2017. Strategi Pengembangan Usaha Ikan Nila di Kabupaten Kuantan Senggigi Propinsi Riau. Jurnal Agribisnis Vol. 19 No. 1 Juni 2017

Rangkuti,Freddy.2015. Analisis SWOT. Jakarta: Gramedia

Sriyoto, Reswita, Hardianto. Analisis Distribusi Pendapatan pada Usaha Ikan Nila di Kecamatan Seginim Kabupaten Bengkulu Selatan AGRISEP Vol. 15 No. 2 September 2015 